MSC 65P99

DOI: $10.14529 / \mathrm{mmp} 190407$

\title{
NUMERICAL STUDY OF THE DYNAMICS OF AIR SEPARATION PROCESS BY PRESSURE SWING ADSORPTION
}

\author{
E.I. Akulinin ${ }^{1}$, O.O. Golubyatnikov ${ }^{1}$, D.S. Dvoretsky ${ }^{1}$, S.I. Dvoretsky ${ }^{1}$ \\ ${ }^{1}$ Tambov State Technical University, Russian Federation \\ E-mails: akulinin-2006@yandex.ru, golubyatnikov_ol@mail.ru,dvoretsky@tambov.ru, \\ sdvoretsky@mail.tstu.ru
}

\begin{abstract}
Using mathematical modelling and the finite element method, we carry out the calculation experiments to study the system connections and regularities of pressure swing adsorption process under the conditions of air separation and oxygen concentration (production). We study the influence of mode and construction variables on the dynamics and technological indicators of the effectiveness of this process. Namely, we study the influence of input variables (composition and temperature of atmospheric air, air pressure at the compressor outlet) on output variables (extraction degree, oxygen purity, unit capacity, etc.) of the studied object in a wide range of control variables (adsorption-desorption cycle time, pressure ratios at adsorption and desorption stages, and oxygen-enriched reverse air flow coefficient). Also, we study the influence of construction parameters (layer height, particle diameter and maximum adsorption volume of the adsorbent) on the amount of adsorption, which is equilibrium with the current concentration of the adsorptive in the gas mixture flow on the outer surface of the adsorbent granules, the value of the kinetic adsorption coefficient (the coefficient of external mass transfer of the adsorptive (mainly nitrogen) from the gas phase into the adsorbent). The results of calculation experiments allow to establish the most promising mode and construction parameters for the optimal design of oxygen enrichment systems by pressure swing adsorption with varying pressure.

Keywords: pressure swing adsorption; oxygen; zeolite 13X; mathematical modelling; numerical study.
\end{abstract}

Dedicated to Professor T.B. Chistyakova on the occasion of her anniversary

\section{Introduction}

In recent decades, the short-cycle non-heat adsorption method, Pressure Swing Adsorption (PSA) with molecular sieves, has been widely used to separate gas mixtures and concentrate gas products on a small scale [1-4]. The performance and quality of the product gas produced in industrial gas separation units using the adsorption method are achieved not only by increasing the volume of the adsorbent, but also by optimizing the time length of the modes and stages that comprise the adsorption-desorption (regeneration) cycle. To this end, there is need for careful preliminary work is needed, which is based on mathematical modelling of adsorption processes with different duration of adsorption and regeneration stages. The mathematical model should take into account the final rate of the pressure profile relaxation along the adsorbent layer with frequent changes in the cycle 
stages, as well as the effect of continuous changes in the gas mixture filtration conditions on the dynamics of the adsorption gas separation $[5,6]$.

Primarily, if the air is enriched with oxygen, then there is adsorption of nitrogen, which is a more sorbable component, and oxygen, which is a less sorbable component of air (on the surface and in the micropores of the granules) during PSA cycle including adsorption and desorption stages. The intensity of the adsorptive mass transfer from the gas mixture to the adsorbent and back (during desorption of the adsorptive) is determined by the equilibrium values of component concentrations in the phases and by kinetics (the adsorptive mass transfer rate from the gas phase to the surface of the granules and into the adsorbent micropore volume) and back (during desorption). During the adsorption by $\mathrm{N}_{2}$ zeolite adsorbents mainly, the following mass and heat exchange processes take place in the adsorbers of the PSA unit: 1) diffusion of $\mathrm{O}_{2}, \mathrm{~N}_{2}$ in the gas-air mixture flow; 2) $\mathrm{O}_{2}, \mathrm{~N}_{2}$ mass transfer and heat exchange between the gas phase and the adsorbent; 3) adsorption of $\mathrm{N}_{2}, \mathrm{O}_{2}$ on the surface and in the micropores of zeolite adsorbent granules with the release of heat, and 4) desorption of $\mathrm{N}_{2}, \mathrm{O}_{2}$ from the micropores and the surface of the granules with the heat adsorption $[1,4,7-9]$. The purpose of this work is to use the mathematical modelling method to study the dynamics, system connections and regularities of the air separation and oxygen production process in order to increase the efficiency of PSA units when enriching air with oxygen.

Table 1

Table of notation

\begin{tabular}{ll}
\hline$a\left(a^{*}\right)$ & component concentration (equilibrium) in the adsorbent, $\mathrm{mol} / \mathrm{m}^{3}$ \\
$d_{g r}\left(S_{s p}\right)$ & diameter of granules, mm (specific surface, $\left.\mathrm{m}^{2} / \mathrm{m}^{3}\right)$ \\
$L\left(D_{A}\right)$ & adsorbent layer length (diameter), $\mathrm{m}$ \\
$G$ & gas-air mixture consumption, $\mathrm{l} / \mathrm{min}$ \\
$k_{p}$ & pressure ratio coefficient, $k_{p}=P_{a d s}^{\text {in }} / P_{\text {des }}^{\text {in }}$ \\
$P(T)$ & gas mixture pressure, $10^{5} \mathrm{~Pa}($ temperature, $\mathrm{K})$ \\
$Q$ & unit capacity, l/min \\
$t_{a d s}, t_{d e s}$ & duration of adsorption and desorption stages, respectively, $\mathrm{s}$ \\
$t_{c}$ & adsorption-desorption cycle time, $\mathrm{s}, t_{c}=t_{\text {ads }}+t_{d e s}$ \\
$W_{0}$ & limiting adsorption volume, $\mathrm{cm}^{3} / \mathrm{g}$ \\
$y$ & component concentration in the gas-air mixture, vol.\% \\
$\beta(\theta)$ & external mass transfer coefficient, $\mathrm{m} / \mathrm{s}($ return flow ratio) \\
$\eta$ & recovery, \% \\
Indices & oxygen, nitrogen, argon and impurities \\
$1,2,3$ & adsorbent (gas phase) \\
a (g) & adsorption (desorption) \\
ads (des) & adsorption-desorption cycle \\
$c$ & input (output) \\
in (out) & minimum (maximum) \\
min (max) & set value \\
set &
\end{tabular}




\section{Mathematical Description of the Dynamics of Oxygen Enrichment Cyclic Adsorption Processes}

The technological process of oxygen production by the method of adsorption air separation with cyclically varying pressure is carried out in a 2-adsorber PSA unit with a granular zeolite adsorbent 13X [8] designed to produce oxygen with a concentration of $90 \ldots 95 \mathrm{vol} \%$ of atmospheric air containing oxygen in the amount of $20,8 \pm 0,5 \mathrm{vol} \%$, nitrogen $-78,2$ vol\% and impurities (argon, carbon dioxide, etc.) - $1 \pm 0,5$ vol $\%[7,8]$.

Our work [7] demonstrates the mathematical description of the dynamics of the adsorption air separation and oxygen concentration processes, as well as the algorithm for solving mathematical model equations, which are a nonlinear partial differential equation of parabolic type describing: 1) the dynamics of the component-wise material balance in the gas-air flow taking into account the longitudinal mixing of the gas-air mixture components in the adsorbent layer; 2) the kinetics of adsorption and desorption processes; 3) the heat distribution in the gas and solid phases taking into account the convective component and heat conductivity; 4) the dynamics of the flow rate along the height of the adsorbent; 5) the pressure dynamics of the gas mixture along the length of the adsorbent (Ergun equation). Herewith, the equilibrium concentration of the sorbed component in the solid phase was calculated using the Dubinin-Radushkevich equation [9], and the mass transfer coefficient was calculated using the criterial equation for the case of gas flow around the layer of spherical particles [10]. To solve the system with the corresponding initial and boundary conditions, we use the finite element method in the Matlab software environment.

\section{Numerical Study of Oxygen Enrichment Adsorption Process in Dynamics}

Table 2 presents the ranges of variation and the nominal values of the mode and construction parameters of the PSA unit while studying the dynamics of oxygen enrichment process.

Table 2

The initial data for calculation experiments

\begin{tabular}{|lll|lll|}
\hline Variables & $\begin{array}{l}\text { Nominal } \\
\text { values }\end{array}$ & $\begin{array}{l}\text { Range of } \\
\text { changes }\end{array}$ & Variables & $\begin{array}{l}\text { Nominal } \\
\text { values }\end{array}$ & $\begin{array}{l}\text { Range of } \\
\text { changes }\end{array}$ \\
\hline$t_{c}, \mathrm{~s}$ & 8 & $1-250$ & $L, \mathrm{~m}$ & 0,3 & $0,2-1$ \\
$y_{2}^{\text {in }}, \mathrm{vol} \%$ & 78,2 & - & $D_{A}, \mathrm{~m}$ & 0,0334 & - \\
$\theta$ & 1,6 & $0-3$ & $W_{0}, \mathrm{~cm}^{3} / \mathrm{g}$ & 0,17 & $0,05-0.5$ \\
$P_{a d s}^{\text {in }}, 10^{5} \mathrm{~Pa}$ & 3 & $2-6$ & $B, 10^{-6} 1 / \mathrm{K}^{2}$ & 6,55 & - \\
$P_{d e s}^{\text {in }}, 10^{5} \mathrm{~Pa}$ & 1 & - & $d_{g r}, \mathrm{~mm}$ & 2 & $0,25-8$ \\
$G^{\text {in }}, \mathrm{l} / \mathrm{min}$ & 10 & - & $y_{1, \text { set }}^{\text {out }}, \mathrm{vol} \%$ & 90 & - \\
$T_{g}^{\text {in }}, \mathrm{K}$ & 293 & $233-313$ & $Q_{\text {set }}, \mathrm{l} / \mathrm{min}$ & 0,5 & - \\
\hline
\end{tabular}

Fig. 1 shows dependencies of the influence of changes in input variables (concentration of impurities and atmospheric air temperature ) on output variables (recovery $\eta$ and oxygen concentration $y_{1, \text { set }}^{\text {out }} \geq 90$ vol. \%) of the PSA unit in a wide range of mode variables (cycle time $t_{c}$, pressure ratio at adsorption and desorption stages $k_{p}$ and the coefficient $\theta$ of 


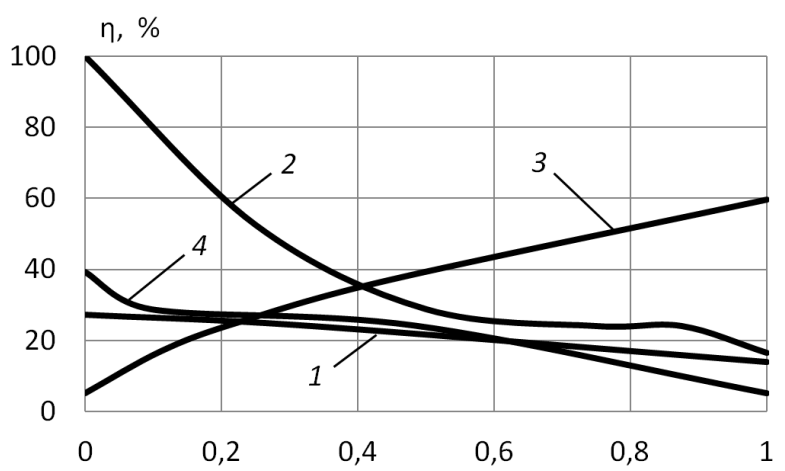

Fig. 1. Dependences of oxygen recovery $\eta$ on: 1 - concentration of impurities in the initial gas-air mixture $y_{3}^{i n} ; 2$-atmospheric air temperature $T_{g}^{i n} ; 3$-limiting adsorption volume of the adsorbent $W_{0} ; 4$-diameter of adsorbent granules $d_{g r}$

oxygen-enriched reverse air flow) and the adsorbent characteristics (limiting adsorption volume $W_{0}$ and diameter of the adsorbent particles $d_{g r}$ ). The values $y_{3}^{\text {out }}, T_{g}^{\text {in }}, W_{0}, d_{g r}$ are normalized on a scale from 0 to 1 .

The analysis of dependencies presented in Fig. 1 shows that increase in the concentration of weakly sorbed impurities in atmospheric air from 0,5 to $2 \mathrm{vol} \%$ and, consequently, decrease in oxygen concentration from 21,3 to 19,8 vol\% lead to decrease in the extraction degree on average by $\sim 2$ times (from 27,3 to $13,9 \%$, Fig. 1, curve 1 ) due to reducing the equilibrium concentration of the adsorptive $a_{2}^{*}$ in the adsorbent. It should be noted that the temperature of the gas-air mixture $T_{g}^{i n}$, the limiting adsorption volume $W_{0}$ and the adsorbent particle diameter $d_{g r}$ significantly affect the efficiency of the mass transfer process. Therefore, the decrease in the mixture temperature from 313 to $233 \mathrm{~K}$ leads to increase in the extraction rate from 16,6 to $99,9 \%$ (Fig. 1, curve 2) due to increase in the equilibrium concentration $a_{2}^{*}$. The increase in $W_{0}$ by an order of magnitude (from 0,05 to $0,5 \mathrm{~cm}^{3} / \mathrm{g}$, Fig. 1, curve 3) leads to increase in the extraction rate also by an order of magnitude (from 5,2 to 59,7\%), which is explained by increase in the equilibrium concentration of the adsorptive $a_{2}^{*}$ in the adsorbent, while decrease in $d_{g r}$ from 8 to 0,25 $\mathrm{mm}$ leads to increase in the extraction degree by $\sim 8$ times (from 5,2 to $39,2 \%$, Fig. 1, curve 4) due to increase in the external surface of particles $S_{s p}$ and the intensity of the mass transfer process from gas to solid phase and vice versa.

Fig. 2 presents the study of the influence of atmospheric air characteristics $\left(y^{i n}, T_{g}^{i n}\right)$ and the adsorbent $\left(W_{0}, d_{g r}\right)$ on the values of mode variables $-k_{p}, \theta, t_{c}$, while ensuring that specified requirements for oxygen purity are $\geq 90 \mathrm{vol} \%$ and the performance of the PSA unit $\left(Q_{\text {set }} \geq 0,5 \mathrm{l} / \mathrm{min}\right)$.

The analysis of the graphs in Fig. 2 (left) shows that with increase in the initial gas-air mixture (at the same time the oxygen content $y_{1}^{\text {in }}$ decreases), it is necessary to increase the equilibrium concentration $a^{*}$ by increase in $k_{p}$ and improving the conditions for adsorbent regeneration at the desorption stage (increasing the reverse flow rate coefficient $\theta$ ), and also reducing the adsorption-desorption cycle time $t_{c}$ due to more intensive processing of the adsorbent layer. The analysis of dependencies in Fig. 2 (right) demonstrates that increasing the temperature $T_{g}^{\text {in }}$ to ensure specified values of oxygen concentration $y_{1, \text { set }}^{\text {out }} \geq 90 \mathrm{vol} \%$ and the unit capacity $Q_{\text {set }} \geq 0,5 \mathrm{l} / \mathrm{min}$, it is necessary to increase the values of the pressure ratio coefficient $k_{p}$ and the reverse flow coefficient $\theta$ with the simultaneous decrease in the adsorption-desorption cycle time $t_{c}$. 

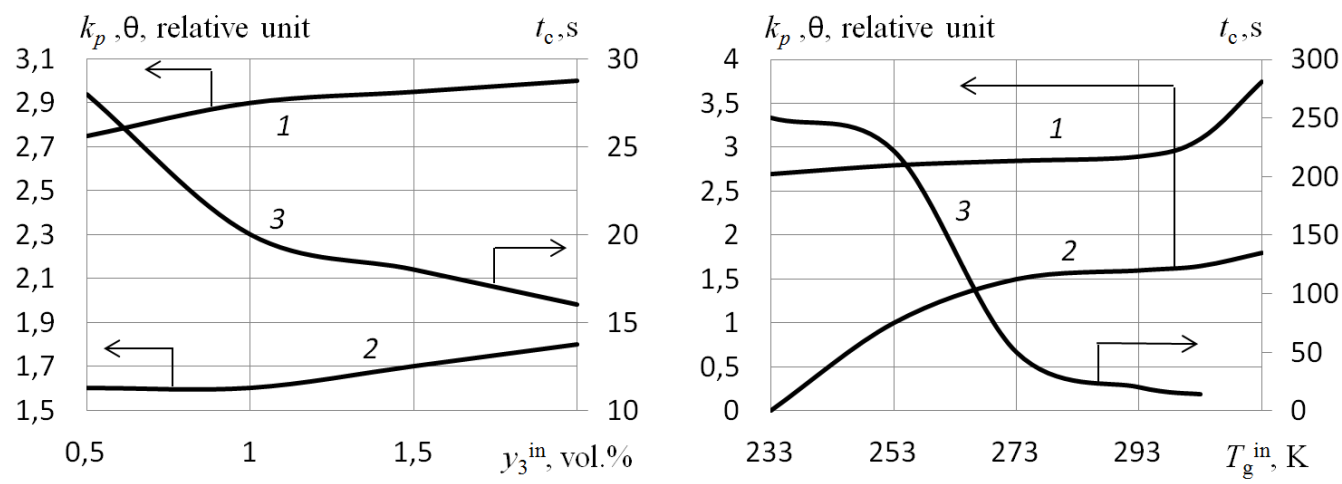

Fig. 2. Dependences of the pressure ratio $k_{p}(1)$, reverse flow $\theta(2)$, and cycle time $t_{c}(3)$ coefficients on: concentration of impurities in the initial gas-air mixture $y_{3}^{\text {in }}$ (left), atmospheric air temperature $T_{g}^{\text {in }}$ (right)
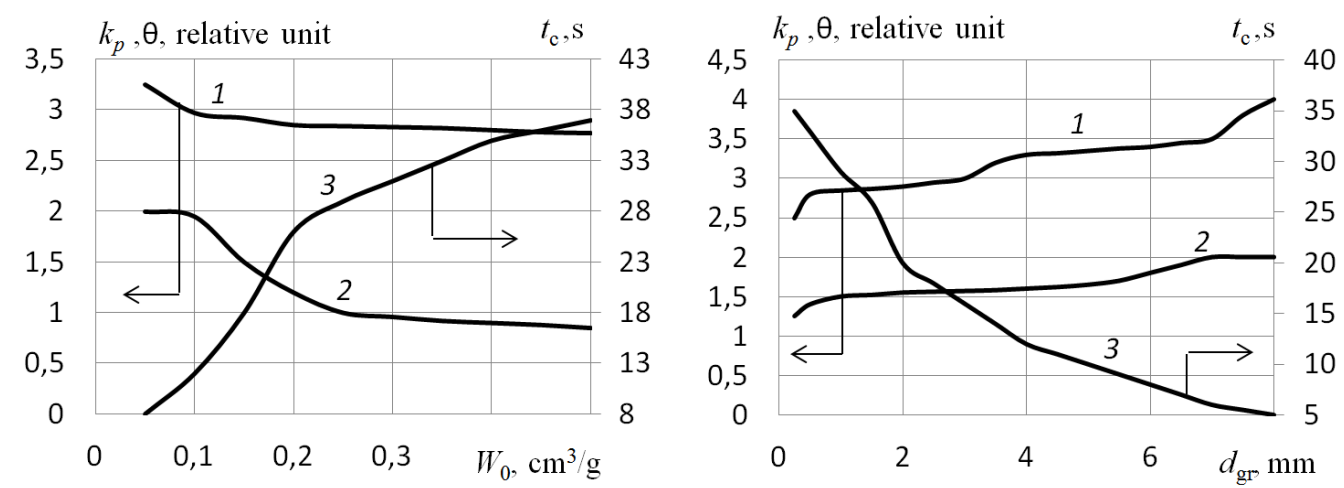

Fig. 3. Dependences of the pressure ratio $k_{p}(1)$, reverse flow $\theta(2)$ and cycle time $t_{c}(3)$ coefficients on: limiting adsorption volume of the adsorbent $W_{0}$ (left), diameter of the adsorbent granules $d_{g r}$ (right)

The analysis of the graphs in Fig. 3 (left) shows that when $W_{0}$ increases from 0,1 to 0,5 $\mathrm{cm}^{3} / \mathrm{g}$ to ensure the specified requirements $\left(y_{1, \text { set }}^{\text {out }} \geq 90 \mathrm{vol} \%, Q_{\text {set }} \geq 0,5 \mathrm{l} / \mathrm{min}\right)$, the value of the pressure ratio coefficient $k_{p}$ by $\sim 2.5 \%$, and the value of $\theta$ which characterizes the fraction of the flow directed to nitrogen desorption from the adsorbent should be reduced by $2,2 \%$. The latter leads to decrease in the energy consumption of the PSA unit due to the use of a less efficient compressor. At the same time, the adsorption-desorption cycle time can be increased by an average of 3 times, which contributes to decrease in the switching frequency of the PSA unit valves and increase in their service life. Since the oxygen enrichment process takes place in the external diffusion area, the diameter of the adsorbent particles $d_{g r}$ increases (Fig. 3 (right)), their specific surface area $S_{s p}$ decreases and, consequently, there is decrease in adsorbent mass transfer rate from the gas phase to the adsorbent and back. Therefore, if the particle diameter of the $13 \mathrm{X}$ adsorbent increases from $2 \mathrm{~mm}$ to $4 \mathrm{~mm}$ for ensuring the specified values of oxygen concentration and the unit capacity, then it is necessary to increase $k_{p}$ and $\theta$ by $\sim 18 \%$, and $7 \%$, respectively, and the adsorption-desorption cycle time $t_{c}$ should be reduced by $\sim 40 \%$. It is most preferable to use the adsorbent with the particle diameter less than 0,5 mm (Fig. 3 (right)), however, this is associated with increase in the adsorbent layer resistance, energy consumption, and deterioration of equilibrium conditions. 
The analysis of the graphs given in Figs. 2, 3 shows that the temperature of the initial gas-air mixture $T_{g}^{i n}$ and the diameter of the adsorbent particles $d_{g r}$ have the most significant effect on the values of mode parameters, the ratio of adsorption and desorption pressures $k_{p}$, the return flow rate coefficient $\theta$, and the cycle time $t_{c}$ ensuring the fulfillment of specified oxygen purity requirements and the PSA unit capacity. Therefore, the use of additional cooling devices and the adsorbent with a smaller diameter of the adsorbent granules while reducing the length $L$ of the adsorbent layer will not only reduce the dimensions of PSA units, but also increase the degree of oxygen extraction.

Fig. 4 presents the analysis of the influence of changes in the construction parameters of the PSA unit with oxygen enrichment (the length of the adsorbent layer $L$ and the particle diameter of the adsorbent $d_{g r}$ ) on the adsorption amount $a^{*}$ which is equilibrium with the current concentration of the adsorptive in the gas mixture flow on the outer surface of the adsorbent granules, the kinetic adsorption coefficient $\beta$ (the adsorptive external mass transfer coefficient (nitrogen) from the gas phase to the adsorbent).

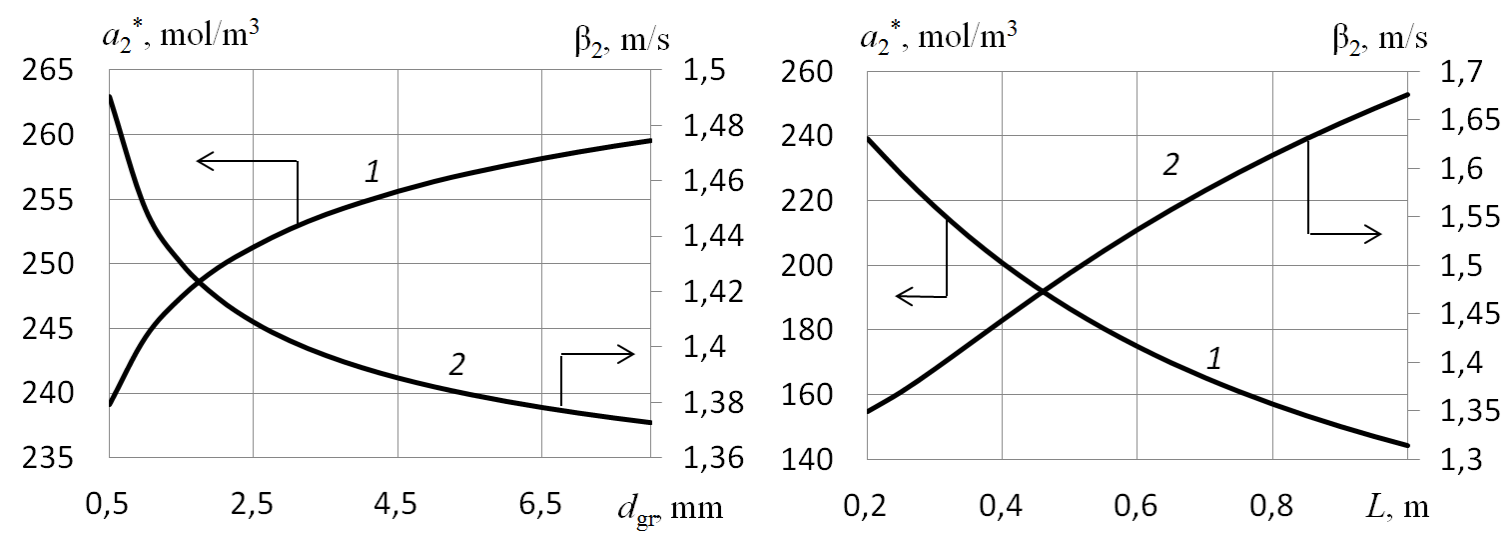

Fig. 4. Dependences of equilibrium nitrogen adsorption in the adsorbent (1) and the nitrogen mass transfer coefficient (2) on the diameter of the granules (left) and the length of the adsorbent bulk layer (right)

The analysis of the graphs given in Fig. 4 shows that with increase in $d_{g r}$ (Fig. 4 (left)) and $L$ (Fig. 4 (right)), the following pattern is observed: the equilibrium concentration value $a_{2}^{*}$ (Fig. 4 (left), dependence 1) increases (decreases, Fig. 4 (right), dependence 1), and the value $\beta$ (Fig. 4 (left), dependence 2) decreases (increases, Fig. 4 (right), dependence $2)$. In the first case, by decrease in the aerodynamic resistance in the adsorbent layer $\Delta P$ according to the Ergun equation and, accordingly, by increase in the current value of the gas-air mixture pressure along the length $L$ of the adsorbent layer. In the second case (with increase in the height of the adsorbent layer in Fig. 4 (right)), the effect can be explained by increase in the aerodynamic resistance of the adsorbent layer, decrease in the current value of the gas-air mixture pressure along the length $L$ of the layer, and increase in the specific surface of the adsorbent. The analysis of the graphs given in Fig. 4 also shows that change in the length of the adsorbent layer leads to increase in equilibrium nitrogen adsorption and nitrogen mass transfer coefficient by 6 times, which is more significant compared with decrease in the particle diameter of the adsorbent $d_{g r}$. In general, the change of $L$ or $d_{g r}$ affects the value of the equilibrium concentration $a_{2}^{*}$ to a greater extent and the value of the mass transfer coefficient $\beta$ to a lesser extent (Fig. 4). 


\section{Conclusions}

We create prerequisites to formulate and study the problem on optimization (in the sense of determining the maximum degree of oxygen extraction) of the oxygen enrichment process in the PSA unit, taking into account the fulfillment of oxygen purity requirements, the unit capacity, and resource saving of the granular adsorbent. New scientific results obtained during this work can be used in the development of mathematical and algorithmic support for designing new automated processes and adsorption process units with cyclically varying pressure for separating and purifying multicomponent gas mixtures.

Acknowledgements. The work was performed in the project part of the State assignment no. 10.3533.2017/PCh.

\section{References}

1. Shumyatskiy Yu.I. Promyshlennye Adsorbtsionnye Processy [Industrial Adsorption Processes]. Moscow, KolosS, 2009.

2. Shokroo E., Farsani D., Meymandi H., Yadoliahi N. Comparative Study of Zeolite 5A and Zeolite 13X in Air Separation by Pressure Swing Adsorption. Korean Journal of Chemical Engineering, 2016, vol. 33, no. 4, pp. 1391-1401.

3. Wu C., Vermula R., Kothare M., Sircar S. Experimental Study of a Novel Rapid PressureSwing Adsorption Based Medical Oxygen Concentrator: Effect of the Adsorbent Selectivity of N2 over O2. Industrial and Engineering Chemistry Research, 2016, vol. 55, no. 16, pp. 4676-4681.

4. Li J.H. The Experimental Study of a New Pressure Equalization Step in the Pressure Swing Adsorption Cycle of a Portable Oxygen Concentrator. Bio-Medical Materials and Engineering, 2014, vol. 24, no. 5, pp. 1771-1779.

5. Chistyakova T.B., Razygrayev A.S., Polosin A.N., Araztaganova A.M. Joint Innovative IT Projects in the Field of Production of Polymeric Sheet Materials. Proceedings of the 2016 IEEE V Forum "Strategic Partnership of Universities and Enterprises of Hi-Tech Branches (Science. Education. Innovations)", St. Petersburg, Saint Petersburg Electrotechnical University LETI, 2016, pp. 61-64.

6. Chistyakova T.B., Polosin A.N. Computer Modelling System of Industrial Extruders with Adjustable Configuration for Polymeric Film Quality Control. Proceedings of 2017 IEEE II International Conference on Control in Technical Systems (CTS), St. Petersburg, Saint Petersburg Electrotechnical University LETI, 2017, pp. 47-50.

7. Akulinin E.I., Golubyatnikov O.O., Dvoretsky D.S., Dvoretsky S.I. Numerical Study of Cyclic Adsorption Processes of Air Oxygen Enrichment in Dynamics. Journal of Physics: Conference Series, 2019, vol. 1278, no. 1, p. 012005.

8. Ruthven D.M., Farooq S., Knaebel K.S. Pressure Swing Adsorption. N.Y., 1993.

9. Dubinin M.M. Adsorbtsiya i poristost' [Adsorption and Porosity]. Moscow, VAKhZ, 1972. (in Russian)

10. Lykov A.V. Teplomassoobmen [Heat and Mass Transfer]. Moscow, Energiya, 1978. (in Russian)

Received November 27, 2018 


\title{
ЧИСЛЕННОЕ ИССЛЕДОВАНИЕ ДИНАМИКИ ПРОЦЕССА РАЗДЕЛЕНИЯ ВОЗДУХА МЕТОДОМ КОРОТКОЦИКЛОВОЙ БЕЗНАГРЕВНОЙ АДСОРБЦИИ
}

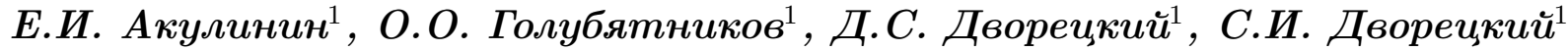 \\ ${ }^{1}$ Тамбовский государственный технический университет, г. Тамбов, \\ Российская Федерация
}

\begin{abstract}
С использованием математического моделирования и метода конечных элементов проведены вычислительные эксперименты по исследованию системных связей и закономерностей процесса короткоцикловой безнагревной адсорбции при разделении воздуха и концентрирования (получения) кислорода. Проведено изучение влияния режимных и конструктивных переменных на динамику и технологические показатели эффективности данного процесса, а именно: 1) входных переменных (состава и температуры атмосферного воздуха, давления воздуха на выходе компрессора) на выходные переменные (степень извлечения, чистоту кислорода, производительность установки и т.п.) объекта исследования в широком диапазоне варьирования управляющих переменных (длительности цикла адсорбция-десорбция, отношения давлений на стадиях адсорбции и десорбции и коэффициента обратного потока воздуха, обогащенного кислородом); 2) конструктивных параметров (высоты слоя, диаметра частиц и предельного адсорбционного объема адсорбента) на величину адсорбции, равновесной текущей концентрации адсорбтива в потоке газовой смеси на внешней поверхности гранул адсорбента, значение кинетического коэффициента адсорбции (коэффициента внешней массоотдачи адсорбтива (преимущественно азота) из газовой фазы в адсорбент). В ходе анализа результатов вычислительных экспериментов установлены наиболее перспективные режимные и конструктивные параметры для оптимального проектирования установок обогащения воздуха кислородом методом короткоцикловой адсорбции с изменяющимся давлением.
\end{abstract}

Ключевые слова: короткочикловая безнагревная адсорбиия; кислород; иеолит $13 X$; математическое моделирование; вычислителъный эксперимент.

\section{Литература}

1. Шумяцкий, Ю.И. Промышленные адсорбционные процессы / Ю.И. Шумяцкий. - М.: КолосС, 2009.

2. Shokroo, E. Comparative Study of Zeolite 5A and Zeolite 13X in Air Separation by Pressure Swing Adsorption / E. Shokroo, D. Farsani, H. Meymandi, N. Yadoliahi // Korean Journal of Chemical Engineering. - 2016. - V. 33, № 4. - P. 1391-1401.

3. Wu, C. Experimental Study of a Novel Rapid Pressure-Swing Adsorption Based Medical Oxygen Concentrator: Effect of the Adsorbent Selectivity of N2 over O2 / C. Wu, R. Vermula, M. Kothare, S. Sircar // Industrial and Engineering Chemistry Research. - 2016. - V. 55, № 16. - P. 4676-4681.

4. Li, J.H. The Experimental Study of a New Pressure Equalization Step in the Pressure Swing Adsorption Cycle of a Portable Oxygen Concentrator / J.H. Li // Bio-Medical Materials and Engineering. - 2014. - V. 24, № 5. - P. 1771-1779.

5. Chistyakova, T.B. Joint Innovative IT Projects in the Field of Production of Polymeric Sheet Materials / T.B. Chistyakova, A.S. Razygrayev, A.N. Polosin, A.M. Araztaganova // Proceedings of the 2016 IEEE V Forum «Strategic Partnership of Universities and Enterprises of Hi-Tech Branches (Science. Education. Innovations)». - St. Petersburg: Saint Petersburg Electrotechnical University LETI, 2016. - P. 61-64. 
6. Chistyakova, T.B. Computer Modelling System of Industrial Extruders with Adjustable Configuration for Polymeric Film Quality Control / T.B. Chistyakova, A.N. Polosin // Proceedings of 2017 IEEE II International Conference on Control in Technical Systems (CTS). - St. Petersburg: Saint Petersburg Electrotechnical University LETI, 2017. - P. 47-50.

7. Akulinin, E.I. Numerical Study of Cyclic Adsorption Processes of Air Oxygen Enrichment in Dynamics / E.I. Akulinin, O.O. Golubyatnikov, D.S. Dvoretsky, S.I. Dvoretsky // Journal of Physics: Conference Series. - 2019. - V. 1278, № 1. - P. 012005.

8. Ruthven, D. M. Pressure Swing Adsorption / D.M. Ruthven, S. Farooq, K.S. Knaebel. - New York, 1993.

9. Дубинин, М.М. Адсорбция и пористость / М.М. Дубинин. - М.: ВАХЗ, 1972.

10. Лыков, А.В. Тепломассообмен / А.В. Лыков. - М.: Энергия, 1978.

Евгений Игоревич Акулинин, кандидат технических наук, доцент кафедры «Технология и оборудование пищевых и химических производств», Тамбовский государственный технический университет (г. Тамбов, Российская Федерация), akulinin2006@yandex.ru.

Олег Олегович Голубятников, кандидат технических наук, старший преподаватель кафедры «Технология и оборудование пищевых и химических производств», Тамбовский государственный технический университет (г. Тамбов, Российская Федерация), golubyatnikov_ol@mail.ru.

Дмитрий Станиславович Дворецкий, доктор технических наук, профессор, зав. кафедрой «Технология и оборудование пищевых и химических производств», Тамбовский государственный технический университет (г. Тамбов, Российская Федерация), dvoretsky@tambov.ru.

Станислав Иванович Дворецкий, доктор технических наук, профессор, профессор кафедры «Технология и оборудование пищевых и химических производств», Тамбовский государственный технический университет (г. Тамбов, Российская Федерация), sdvoretsky@mail.tstu.ru.

Поступила в редакиию 27 ноября 2018 г. 